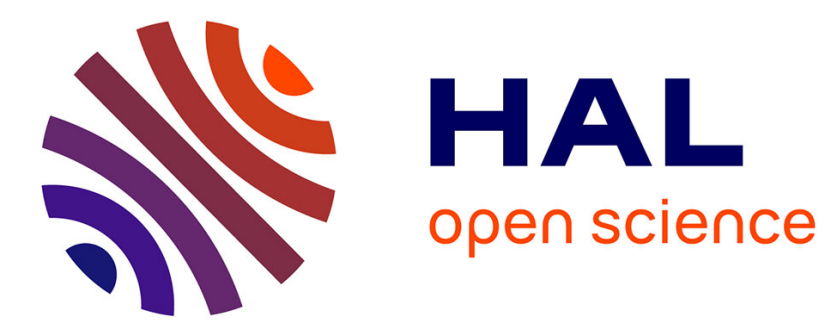

\title{
Electrophoretic variation in four french populations of domesticated rainbow trout (Salmo gairdneri) \\ René Guyomard
}

\section{To cite this version:}

René Guyomard. Electrophoretic variation in four french populations of domesticated rainbow trout (Salmo gairdneri). Canadian journal of genetics and cytology. Journal canadien de genetique et de cytologie, 1981, 23, pp.33-47. 10.1139/g81-005 . hal-01602926

\section{HAL Id: hal-01602926 \\ https://hal.science/hal-01602926}

Submitted on 2 Jun 2020

HAL is a multi-disciplinary open access archive for the deposit and dissemination of scientific research documents, whether they are published or not. The documents may come from teaching and research institutions in France or abroad, or from public or private research centers.
L'archive ouverte pluridisciplinaire HAL, est destinée au dépôt et à la diffusion de documents scientifiques de niveau recherche, publiés ou non, émanant des établissements d'enseignement et de recherche français ou étrangers, des laboratoires publics ou privés.

\section{다(1)(2)}

Distributed under a Creative Commons Attribution - ShareAlikel 4.0 International 


\title{
ELECTROPHORETIC VARIATION IN FOUR FRENCH POPULATIONS OF DOMESTICATED RAINBOW TROUT (SALMO GAIRDNERI)
}

\author{
RENÉ GuYOMARD \\ Laboratoire de Physiologie des Poissons, Institut National de la Recherche Agronomique, 78350 \\ Jouy en Josas, France
}

\begin{abstract}
Electrophoretic variation of 12 enzyme systems, representing 26 loci in four strains of domesticated rainbow trout (Salmo gairdneri Richardson) were studied. The variances among and within strains, estimated from observed frequencies, were compared to data of other studies of biochemical polymorphism carried out in this species. These preliminary results show that a large proportion of the variability in rainbow trout is present in the French hatchery stocks studied and that isolation of these groups for several generations has not caused a significant genetic differentiation as compared to all the domesticated strains studied.
\end{abstract}

Nous avons examiné les variations électrophorétiques de 12 systèmes enzymatiques, représentant 26 locus chez 4 populations domestiques de Truite Arc-en-ciel (Salmo gairdneri Richardson). Les variabilités inter et intra-populations, estimées à partir des fréquences observées, ont été comparées aux données provenant d'autres études de polymorphisme biochimique réalisées sur la même espèce. De cette étude préliminaire, il ressort qu'une large part de la variabilité de l'espèce Truite Arc-en-ciel est présente dans les stocks piscicoles français étudiés et que l'isolement de ces groupes durant plusieurs générations ne s'est pas traduit par une différenciation génétique significative vis-à-vis de l'ensemble des populations domestiques étudiées.

\section{Introduction}

The rainbow trout species (Salmo gairdneri) poses the following taxonomic problems at diverse levels.

- Its definition as compared to other "evolving lineages" of the genus Salmo in northwestern America. The polygenetic relations of the rainbow trout with such forms as Salmo aguabonita and S. apache are still a controversial subject (Gold, 1977);

- Its genetic structure; at present, rainbow trout seems to be a heterogeneous species, including many geographic (S. aquilarium, S. smaragdus, S. regalis) and ecologic (anadromous, sedentary populations in rivers or lakes) forms. The existence of sympatric lake populations has been reported twice (Behnke, 1972).

All the breeding stocks which, as affected either by șelection due to domestication or by random sampling (initial or at each breeding cycle), have differentiated into one or more original sub-units should be added to these natural populations.

Among the various techniques available for phylogenetic studies, those using the genetic variations in proteins have proven particularly useful; they have been widely employed in studies in the genus Salmo in northwestern America, indicating the phylogenetic relations within that group (Gold, 1977; Allendorf and Utter, 1974).

Work carried out on the migratory form of rainbow trout (Allendorf, 1975; Utter and Allendorf, 1977) has revealed two genetically differentiation groups corresponding to two distinct geographical areas, one coastal and the other inland. Those authors invalidated the conventional divisions according to seasonal return to the river and reported no genetic diversity between anadromous and resident forms in the same river (Utter and Allendorf, 1977).

Manuscript received February 6, 1980.

Can. J. Genet. Cytol. 23: 33-47, 1981. 
The rainbow trout was introduced into Europe some 100 years ago (Mac Crimmon, 1971); we wished to determined what part of the genetic variability of the species was thus introduced and maintained. This paper reports the electrophoretic variants of different enzyme systems in some rainbow trout populations used in French fish culture and attempts to answer three questions:

1) what is the proportion of heterozygosity in these populations

2) what is their degree of differentiation

3) what is their biochemical polymorphism as compared to the main body of the species.

In this article, we present some preliminary results obtained in four of these populations.

\section{Material and Methods}

\section{Strains}

The four strains studied were taken from three different fish farms and were chosen from a list of farms whose breeding stocks had not been renewed from the outside for at least ten generations. No more data are available about the history of these strains. In one farm, we sampled two different groups, one in 1977 and the other in 1978. The one to twoyear old fish were killed and stored at $-20^{\circ} \mathrm{C}$, and their tissues were tested during the next two weeks. These four strains are named $S_{1}-77, S_{1}-78, S_{2}, S_{3}$ and the sizes of samples from these ones are respectively $63,40,60$ and 40 .

\section{Extraction}

The extracts were obtained after grinding in a $0.01 \mathrm{M}$ phosphate buffer $\mathrm{pH} 7.4$ (weight/ volume). The ground heart, eye and muscle were centrifuged at $4000 \mathrm{xg}$ for $30 \mathrm{~min}$, and sometimes re-centrifuged; liver extracts were centrifuged at $26000 \times \mathrm{xg}$ for $1.5 \mathrm{~h}$. All manipulations were carried out at $4^{\circ} \mathrm{C}$.

\section{Electrophoresis}

$300 \mathrm{ml}$ of $12 \%$ Connaught starch gel were poured into $6 \times 170 \times 225 \mathrm{~mm}$ molds. The clear supernatants were individually drawn into $6 \times 6 \mathrm{~mm}$ squares of Whatman $3 \mathrm{M}_{\mathrm{M}}$ paper inserted into the gel. Buffers, electrophoretic conditions and the staining solutions of each system are shown in Table I. The gels were refrigerated during migration with ice packs.

\section{Designation of Alleles}

The locus designation adopted here conforms to the conventional nomenclature (Allendorf, 1975; Busack et al., 1979). The most frequent alleles were arbitrarily designated by mobility 1.00 .

\section{Measurement of Genetic Distance and Proportion of Polymorphism}

We used the formula proposed by Nei (1975). If $x_{i j}$ is the frequency of allele $i$ for a locus in a population $\mathrm{j}$, gene diversity is expressed by $\mathrm{Hj}=1-\sum_{i} \mathrm{x}^{2} \mathrm{ij}$ which is equivalent to average heterozygosity, assuming Hardy-Weinberg genotype proportions. Genetic distance between populations $j$ and $j^{\prime}$ is measured by $D j^{\prime} j^{\prime}=\frac{1}{2} \sum_{i}\left(x_{i j}-x_{i j}{ }^{\prime}\right)^{2}$. The overall genic diversity of a group of populations is $H_{T}=1-\sum_{i} x^{2}{ }_{i}$ with $x_{i}=\sum_{j} w_{j} x_{i, j}$ where wj is the coefficient of the weight of the population $j$. In this paper we used the same coefficient for each population $\left(\mathrm{w}_{\mathrm{j}}=\frac{1}{\mathrm{~N}}\right.$ ) with $\mathrm{N}$ representing the number of populations. Extensions to several loci are immediate. 
TABLE I

Electrophoretic and staining techniques

\begin{tabular}{|c|c|c|c|}
\hline Systems & $\begin{array}{l}\text { Examined } \\
\text { tissue }\end{array}$ & Electrophoretic conditions & Revelation \\
\hline $\begin{array}{l}\text { Alcohol } \\
\text { dehydrogenase } \\
\text { (ADH) }\end{array}$ & Liver & $\begin{array}{l}\text { Ridgway buffer (Ridgway } \\
\text { et al., 1970); } 60 \mathrm{Ma} \text {, } \\
\text { voltage max } 350 \text { volts; } \\
\text { migration during } 3 \mathrm{~h}\end{array}$ & $\begin{array}{l}\text { Ethanol } 5 \mathrm{ml} \text {; NAD } 15 \mathrm{mg} \text {; NBT } 5 \mathrm{mg} ; \\
\text { PMS } 5 \mathrm{mg} ; 0.05 \mathrm{M} \text { Tris-HCl, pH } 8.00: 100 \\
\mathrm{ml}\end{array}$ \\
\hline $\begin{array}{l}\text { Creạtine } \\
\text { kinase (CK) }\end{array}$ & Muscle & Ridgway buffer & $\begin{array}{l}\text { 1) Specific staining : creatine kinase, } \\
\text { disodium salt } 20 \mathrm{mg} \text {; NBT } 5 \mathrm{mg} \text {; PMS } 10 \\
\text { mg; NADP } 5 \mathrm{mg} \text {; adenosine } 5 \text { diphosphate } \\
30 \mathrm{mg} \text {; glucose } 20 \mathrm{mg} \text {; hexokinase } 100 \\
\text { units;g-6-pdh } 20 \text { units; } 0.05 \mathrm{M} \text { Tris-HCl, } \\
\text { pH } 8.00: 100 \mathrm{ml} \text { 2) Amidoblack staining }\end{array}$ \\
\hline $\begin{array}{l}\text { Glutamate } \\
\text { oxaloacetate } \\
\text { transaminase } \\
\text { (GOT) }\end{array}$ & Heart & $\begin{array}{l}\text { Morpholino-citrate buffer } \\
\text { (Clayton and Tretiak, } \\
\text { 1972) } 65 \mathrm{~mA} ; 320 \text { volts } \\
\text { during } 5 \mathrm{~h}\end{array}$ & $\begin{array}{l}\text { Aspartic acid : } 100 \mathrm{mg} \text {; Pyridoxal } 5^{\prime} \\
\text { phosphate } 10 \mathrm{mg} \text {; Fast blue BB salt } 100 \\
\text { mg; } \alpha \text {-keto-glutaric acid } 80 \mathrm{mg} ; 0.2 \mathrm{M} \text { Tris- } \\
\mathrm{HCl} \text { pH } 8.00: 100 \mathrm{ml}\end{array}$ \\
\hline $\begin{array}{l}\alpha \text {-glycero- } \\
\text { phosphate } \\
\text { dehydrogenase } \\
\text { (GPDH) }\end{array}$ & Muscle & $\begin{array}{l}0.1 \mathrm{M} \text { Tris-phosphate } \mathrm{pH} \\
7.4 \mathrm{MA} ; 150 \text { volts during } \\
90 \mathrm{MA} ; \\
5 \mathrm{~h}\end{array}$ & $\begin{array}{l}\text { DL } \alpha \text { glycerophosphate, disodium salt } 80 \\
\text { mg; PMS } 5 \mathrm{mg} \text {; NAD } 25 \mathrm{mg} \text {; NBT } 5 \mathrm{mg} \text {; } \\
\text { EDTA Trisodium salt } 16 \mathrm{mg} \text {; } 0.05 \mathrm{M} \text { Tris- } \\
\mathrm{HCl} \text {, pH } 8.00: 100 \mathrm{ml}\end{array}$ \\
\hline $\begin{array}{l}\text { Isocitrate } \\
\text { dehydrogenase } \\
\text { (IDH-s) }\end{array}$ & Liver & $\begin{array}{l}\text { 1) } 0.1 \mathrm{M} \text { Tris-phosphate } \\
\text { pH } 7.490 \mathrm{MA} ; 150 \text { volts } \\
\text { during } 5 \mathrm{~h} \\
\text { 2) sodium citrate buffer } \\
\text { (Cross and Payne, } 1977 \text { ); } \\
100 \mathrm{~mA} ; 130 \text { volts during } \\
9 \mathrm{~h}\end{array}$ & $\begin{array}{l}\text { D-L-isocitric acid, trisodium salt } 30 \mathrm{mg} \text {; } \\
\text { NADP } 5 \mathrm{mg} \text {; NBT } 5 \mathrm{mg} \text {; PMS } 5 \mathrm{mg} ; \\
\mathrm{MgSO}_{4} 40 \mathrm{mg} ; 0.05 \mathrm{M} \text { Tris- } \mathrm{HCl} \mathrm{pH} 8.00: \\
100 \mathrm{ml}\end{array}$ \\
\hline $\begin{array}{l}\text { Mitochondrial } \\
\text { isocitrate } \\
\text { dehydrogenase } \\
\text { (IDH-m) }\end{array}$ & Heart & $\begin{array}{l}0.1 \mathrm{M} \text { Tris-phosphate } \mathrm{pH} \\
7.4 \\
90 \mathrm{~mA}, 150 \text { volts during } \\
5 \mathrm{~h}\end{array}$ & $\begin{array}{l}\text { D-L-isocitric acid, trisodium salt } 30 \mathrm{mg} \text {; } \\
\text { NADP } 5 \mathrm{mg} \text {; NBT } 5 \mathrm{mg} \text {; PMS } 5 \mathrm{mg} \text {; } \\
\mathrm{MgSO}_{4} 40 \mathrm{mg} ; 0.05 \mathrm{M} \text { Tris-HCl } \mathrm{pH} 8.00: \\
100 \mathrm{ml}\end{array}$ \\
\hline $\begin{array}{l}\text { Lactate } \\
\text { dehydrogenase } \\
\text { (LDH) }\end{array}$ & $\begin{array}{l}\text { Muscle } \\
\text { Heart } \\
\text { Eye }\end{array}$ & Ridgway buffer & $\begin{array}{l}\text { Lactic acid, lithium salt } 200 \mathrm{mg} ; \mathrm{NAD} 15 \\
\mathrm{mg} \text {; NBT } 5 \mathrm{mg} \text {; PMS } 5 \mathrm{mg} \text {; Tris- } \mathrm{HCl} \mathrm{pH} \\
8.00100 \mathrm{ml} .\end{array}$ \\
\hline $\begin{array}{l}\text { Malate } \\
\text { dehydrogenase } \\
(\mathrm{MDH})\end{array}$ & $\begin{array}{l}\text { Liver } \\
\text { Muscle } \\
\text { Heart }\end{array}$ & $\begin{array}{l}\text { Morpholino-citrate buffer } \\
\text { (Clayton and Tretiak, } \\
1972 \text { ) } \\
65 \mathrm{~mA} ; 320 \text { volts during } \\
5 \mathrm{~h}\end{array}$ & $\begin{array}{l}\text { L-Malic acid, monosodium salt } 500 \mathrm{mg} \text {; } \\
\text { NAD } 40 \mathrm{mg} ; \text { NBT } 20 \mathrm{mg} \text {; PMS } 5 \mathrm{mg} ; \\
0.15 \mathrm{M} \text { Triethano-lamine-HCl pH } 9.0: 100 \\
\text { ml }\end{array}$ \\
\hline $\begin{array}{l}\text { Phosphoglucose } \\
\text { isomerase } \\
\text { (PGI) }\end{array}$ & Muscle & $\begin{array}{l}0.1 \mathrm{M} \text { Tris-phosphate } \mathrm{pH} \\
7.4 \\
90 \mathrm{~mA} ; 150 \text { volts during } \\
5 \mathrm{~h}\end{array}$ & $\begin{array}{l}\text { Fructose-6-phosphate } 12.5 \mathrm{mg} \text {; NADP } 0.8 \\
\text { mg; NBT } 1.5 \mathrm{mg} \text {; PMS } 1.5 \mathrm{mg} \text {; G-6-PDH } \\
25 \text { units; } 0.05 \mathrm{M} \text { Tris- } \mathrm{HCl} \mathrm{pH} 8.004 \mathrm{ml} \text {. } \\
10 \times 22.5 \mathrm{~cm} \text { rectangle of Whatman } \mathrm{n}^{\circ} 1 \\
\text { paper, impregnated with this solution, is } \\
\text { applicated on the gel }\end{array}$ \\
\hline $\begin{array}{l}\text { Phosphogluco- } \\
\text { mutase (PGM) }\end{array}$ & Muscle & $\begin{array}{l}0.1 \mathrm{M} \text { Tris-phosphate } \mathrm{pH} \\
7.4 \\
90 \mathrm{~mA}, 150 \text { volts during } \\
5 \mathrm{~h}\end{array}$ & $\begin{array}{l}\text { Same staining procedure; } 15 \mathrm{mg} \text { of } \\
\text { Glucose-1-phosphate instead of F-6- } \\
\text { phosphate }\end{array}$ \\
\hline $\begin{array}{l}\text { Transferrin } \\
\text { (Tf) }\end{array}$ & Serum & Ridgway buffer & Amidoblack \\
\hline $\begin{array}{l}\text { Superoxyde } \\
\text { dismutase } \\
\text { (S.O.D.) }\end{array}$ & Liver & Ridgway buffer & Stained in the same time as ADH \\
\hline
\end{tabular}

\section{Estimation of Allelic Frequencies}

An extensive gene duplication was found in salmonid species, confirming that they have been subjected to a tetraploidization during their evolution. These species now have a disomic 
mode of inheritance; at the molecular level this means that in some tissues, some enzyme systems are coded by two loci. Since the allelic relations between these four genes and their assignment to each locus could not always be determined on the electrophoregrams, sometimes the genotypes could be only partially ascertained for two loci of a duplicate. We had this problem with the glutamic oxaloacetic transaminase (GOT), malate dehydrogenase (MDH) and isocitrate dehydrogenase (IDH) systems, and therefore adopted the following rule: if $n_{i j}$ was the total observed number of genes of a given allelic type $i$ and $n_{i}$ the total number of genes sampled, the genetic distance, computed with these two loci was minimal if the frequency $\frac{n_{i j}}{2 n_{j}}$ was assigned to the allele $i$ at each of the two loci. This was the case of

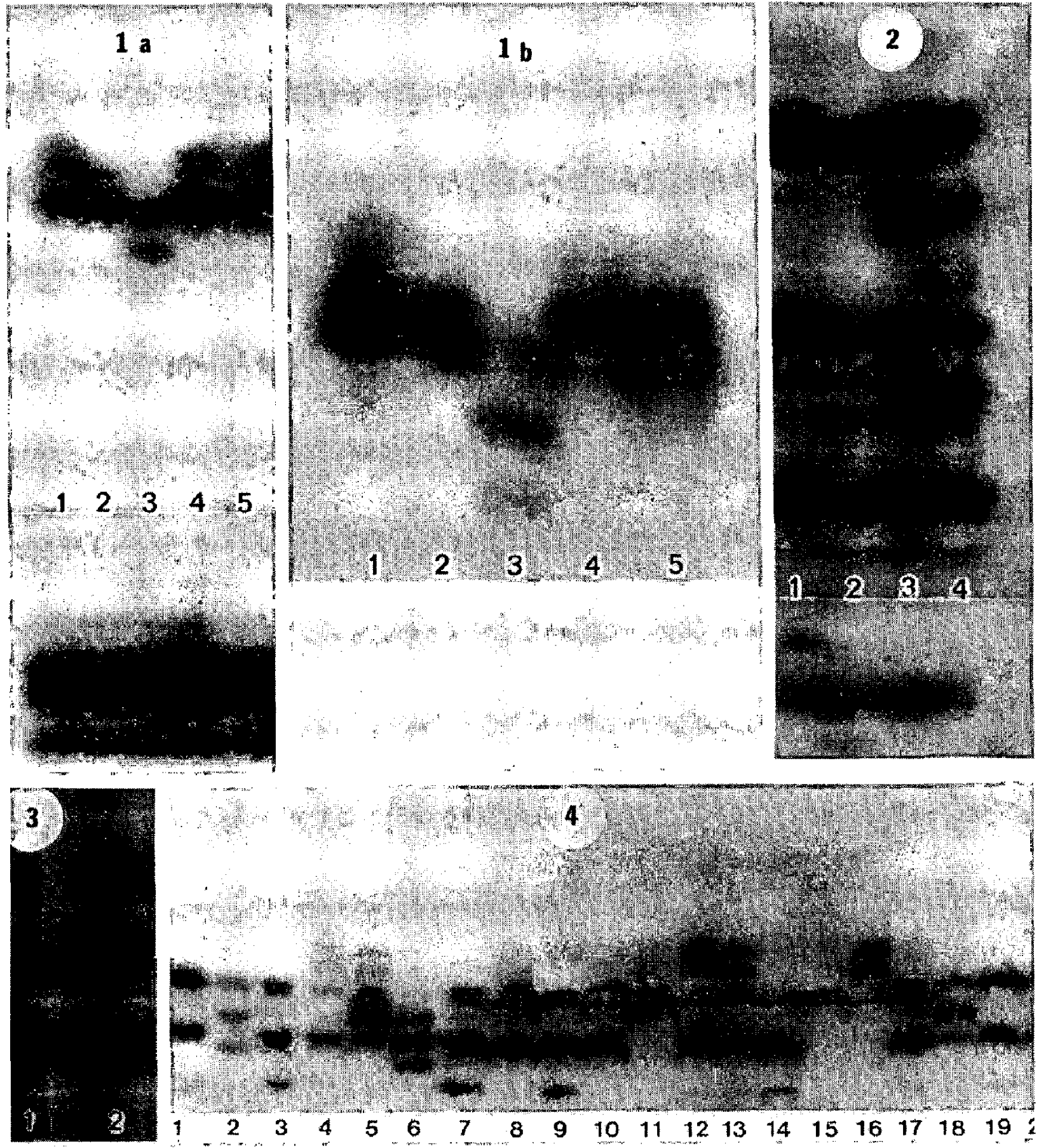

FIG. 1. 1a: GOT in heart; 1b : details of polymorphism corresponding to loci Got1 and 2 . FIG. 2. MDH in heart. FIG. 3. IDH-m in heart. FIG. 4. Idh-s 3 and 4; presumed genotypes : 1, 8, 10, $17,19,20$. Idh $3-4(1.00 / 1.00 / 1.00 / 0.38) ; 2:$ Idh $3-4(1.00 / 1.00 / 1.00 / 0.62) ; 3,7,9,14:$ Idh 3-4 $(1.00 / 1.00 / 0.38 / 0.38) ; 4,12,13:$ Idh $3-4(1.00 / 1.00 / 0.38 / 1.31) ; 5:$ Idh $3-4(1.00 / 1.31 / 0.69 / 0.69) ; 6:$ Idh $3-4(1.00 / 0.69 / 0.69 / 0.38) ; 11,15:$ Idh $3-4(1.00 / 1.00 / 1.00 / 1.00) ; 16:$ Idh $3-4(1.00 / 1.00 / 1.00 /$ $1.31) ; 18:$ Idh $3.4(1.00 / 1.00 / 0.69 / 0.69)$. 


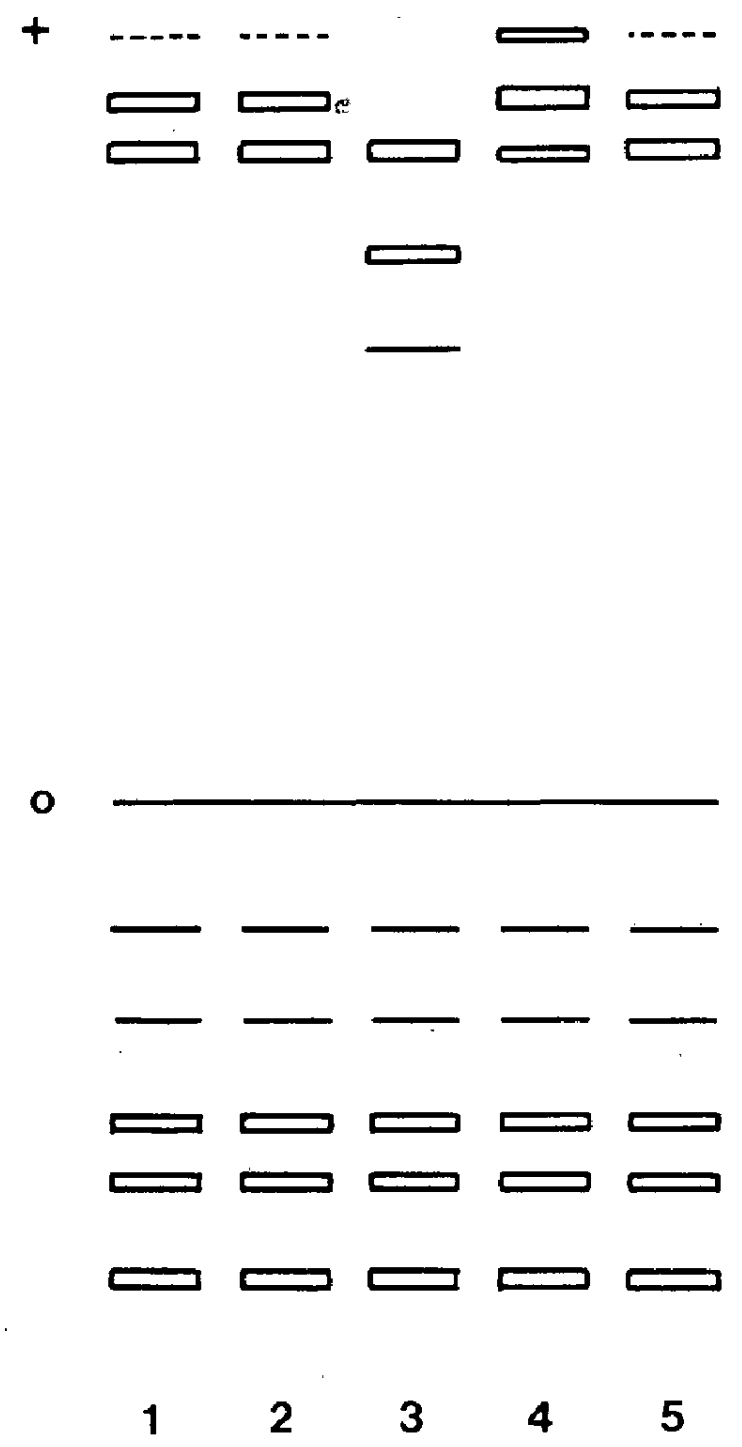

FIG. 5. Genetic interpretation of FIG. 1a. 1, 2 and $5:$ Got $1-2(1.00 / 1.00 / 1.00 / 1.17) ; 3:$ Got 1 $2(1.00 / 1.00 / 1.00 / 0.70) ; 4$ : Got $1-2(1.00 / 1.00 / 1.17 / 1.17)$.

IDH and MDH. The whole of the values $\frac{n_{i j}}{2 n_{j}}(j=1, \ldots, n)$ minimized the mean genetic distance $\frac{1}{N^{2}} \sum_{j} \sum_{j} \cdot w_{j} w_{j} D_{j, j}$, where $N$ is the number of populations, but maximized $\sum_{j} H_{j} w_{j}$ as well as the overal genic diversity $H_{T}$. The degree of heterogeneity of the populations group $\frac{i}{N^{2}} \frac{\sum_{j} \sum_{i} w_{j} w_{j} D_{j i}}{H_{r}}$ was also minimum, but the dendrogram of those values did not necessarily correspond to that obtained from the true frequencies. For GOT, we considered the possibility that only one of the two loci might be polymorphic; both hypotheses (one or two polymorphic loci) were tested using the law of Hardy-Weinberg.

Comparison with Results in the Literature

Two papers (Allendorf, 1975; Busack et al., 1979) have furnished data on nine stocks from American fish farms; we have compared these with our results. For the betweenpopulation comparisons, we used only the loci common to the three studies. For each one, we accepted the homologies of the alleles most frequently described in the three articles; this was well corroborated by the electrophoretic mobilities of other alleles. For both the MDH and IDH systems, we regrouped some observed alleles which could not be differentiated in the other two studies (see Results).

\section{Construction of Dendrograms}

The dendrogram indicating the genetic distances between the 13 populations was constructed using a Fortran program provided by Dr. Neï. 


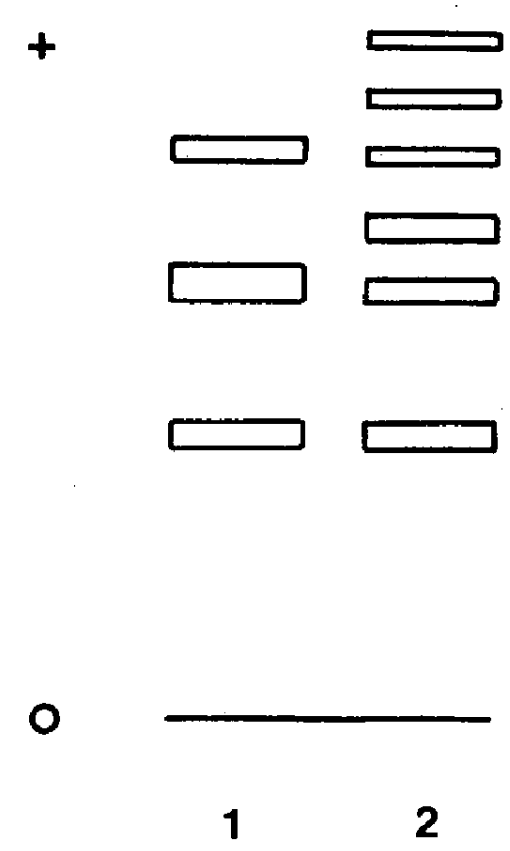

FiG. 6. Genetic interpretation of Fig. 3. $1:$ Idh-2 (1.00/1.00); $2:$ Idh-2 (1.00/1.20).

\section{Results}

\section{Description and Interpretation of Electrophoregrams}

We studied 11 enzymatic systems, and the electrophoregrams obtained agreed with the results of the other two authors (Allendorf, 1975; Busack et al, 1979). Table II shows the models currently used in the genetic determinism of those systems and preferentially indicated the references mentioning "genetic tests" carried out on rainbow trout species. The other methods sometimes used are genetic studies in phylogenetically close species and the distribution of enzymatic forms in the various tissues. Figures 1, 2, 3, 4, 5, 6 and 7 illustrate some of the variants found.

The electrophoretic behavior of GOT deserves attention; in Ridgway and Trisphosphate buffers, the system was monomorphic. This agrees with the observations of Allendorf (1975) and Busack et al. (1979). However, at pH 6.1 extreme variations resembling those of MDH-B and suggesting a genetic control of two loci, were found (Figs. 1a and $1 \mathrm{~b}$ ). Table II also presents results on the duplicated or unduplicated state of the different loci studied. Whether or not duplication is found partially depends on technique sensitivity, as illustrated for $\alpha$-glycerophosphate dehydrogenase ( $\alpha$-GPDH) (Allendorf, 1975). We estimated a total of 26 loci for the 11 enzymatic systems.

\section{Allelic Frequencies}

Table III shows the alleles found and their computed frequencies at each locus. For IDH-s and MDH-B, each allele was presumed to have the same frequency at the two loci coding for each system (minimal genetic distance). For GOT according to the test of the two hypotheses (minimization of genetic distance and only one polymorphic locus) using the law of Hardy-Weinberg, we retained the second one in agreement with this law (Table IV).

The distribution of the allelic frequencies in each stock, followed a conventional pattern: at most loci a high frequency allele common to all the populations was found.

We usually observed a larger number of alleles than mentioned in the other two studies of rainbow trout populations (Allendorf, 1975; Busack et al., 1979). 
TÁBLE II

Genetic determinism of studied enzymatic systems

\begin{tabular}{|c|c|c|c|c|}
\hline Systems & $\begin{array}{l}\text { Enzyme } \\
\text { structure }\end{array}$ & $\begin{array}{c}\text { Genetic } \\
\text { determinism }\end{array}$ & Duplication & References \\
\hline APH & dimeric & 1 locus & no & Allendorf (1975): mendelian inheritance studies on rainbow trout \\
\hline CK & monomeric & $\begin{array}{l}2 \text { loci: } \\
\text { Cpk-1 variable } \\
\text { Cpk-2 fixed }\end{array}$ & $\begin{array}{l}\text { yes, disomic } \\
\text { heredity }\end{array}$ & Allendorf (1975): mendelian inheritance studies on rainbow trout \\
\hline GOT & dimeric & $\begin{array}{l}2 \text { loci: } \\
\text { Got }-1 \text { fixed } \\
\text { Got- } 2 \text { variable }\end{array}$ & idem & Allendorf (1975): mendelian inheritance studies on rainbow trout \\
\hline$\alpha-\mathrm{GPDH}$ & idem & $\begin{array}{l}2 \text { loci: } \\
\alpha \text { gpdh-1 fixed } \\
\alpha \text { gpdh-2 variable }\end{array}$ & idem & $\begin{array}{l}\text { Utter et al. (1973); May et al. (1979); mendelian inheritance tests on brook } \\
\text { trout (Salvelinus fontinalis) and lake trout (Salvelinus namaycush) } \times \text { brook } \\
\text { trout }\end{array}$ \\
\hline IDH+s & idem & $\begin{array}{l}2 \text { loci: Idh-3 and } \\
\text { Idh-4 variable }\end{array}$ & idem & Allendorf and Utter (1973): inheritance studies on rainbow trout \\
\hline IDH-m & idem & $\begin{array}{l}2 \text { loci: Idh-1 } \\
\text { fixed, Idh-1 } \\
\text { variable }\end{array}$ & idem & . \\
\hline LDH-M & tetrameric & $\begin{array}{l}2 \text { loci: Ldh-1 and } \\
\text { Ldh-2 fixed }\end{array}$ & idem & Bailey et al. (1976) \\
\hline LDH-H & idem & $\begin{array}{l}2 \text { loci: } L d h-3 \text { and } \\
\text { Ldh-4 variable }\end{array}$ & idem & Wright et al. (1975): inheritance studies on rainbow trout \\
\hline LDH-E & idem & $\begin{array}{l}1 \text { locus, Ldh-5 } \\
\text { variable }\end{array}$ & no & Wright et al. (1975): inheritance studies on rainbow trout \\
\hline $\mathrm{MDH}-\mathrm{A}$ & dimeric & 2 loci: Mdh 1 and 2 & yes & Allendorf (1975): inheritance studies on rainbow trout \\
\hline MDH-B & idem & $\begin{array}{l}2 \text { loci: Mdh } 3 \text { and } \\
4 \text {, variable }\end{array}$ & $\begin{array}{l}\text { yes disomic } \\
\text { heredity }\end{array}$ & Bailey et al. (1970): inheritance studies on rainbow trout \\
\hline PGI & idem & $\begin{array}{l}3 \text { loci: Pgi } 1 \text {, } \\
2 \text { and } 3 \text {. }\end{array}$ & $\begin{array}{l}\text { idem for Pgi-1 } \\
\text { and } 2 \text {, Pgi-3 } \\
\text { not duplicated }\end{array}$ & $\begin{array}{l}\text { Avise and Kitto (1973); Schmidtke et al. (1975); May et al. (1979): } \\
\text { inheritance studies on brook trout }\end{array}$ \\
\hline PGM & monomeric & 1 locus variable & no & $\begin{array}{l}\text { Roberts et al. (1979); Utter et al. (1973): inheritance studies on sockeye } \\
\text { salmon (Oncorhynchus nerka) }\end{array}$ \\
\hline TO & dimeric & idem & idem & Utter et al. (1973): inheritance studies on rainbow trout \\
\hline Tf & monomeric & idem & idem & idem \\
\hline
\end{tabular}




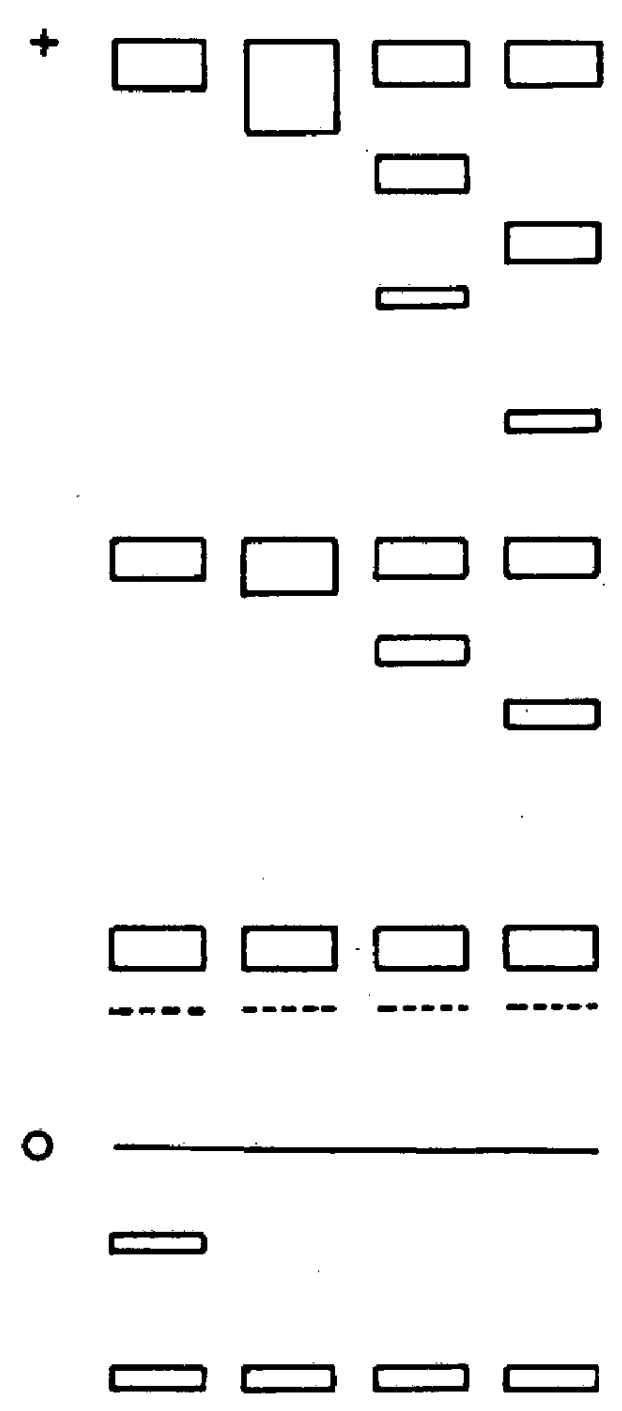

\section{$\begin{array}{llll}1 & 2 & 3 & 4\end{array}$}

Fig. 7. Genetic interpretation of Fig. 5 for anodal variations. Cathodal part should correspond to mitochondrial $\mathrm{MDH}$.

$1:$ Mdh 3-4 (1.00/1.00/1.00/1.00); $2:$ Mdh 3-4 (1.00/1.00/1.00/0.96) ;

$3:$ Mdh 3-4 (1.00/1.00/1.00/0.79); $4:$ Pdh 3-4 (1.00/1.00/1.00/0.70)

This is certainly not related to the sample size of the populations, but to true differences between the frequencies or more likely to the electrophoretic techniques used.

The eight loci, A-gpdh 1 and 2, Idh 3 and 4, Mdh 3 and 4, Pgm and Sod, common to the three studies, were used for subsequent comparisons. These eight loci give highly biaised absolute values, but we are mainly interested in relative comparisons. Four relatively variable systems (IDH-m, GOT, CK and p-ALB), either studied under very different electrophoretic conditions or not examined in the overall populations, were discarded.

For IDH-s and MDH-B, we regrouped the following alleles; Idh (1.31-1) and (1.31-2), Idh (0.69) and (0.62), Mdh (1.00) and (0.96), Mdh (0.79) and Mdh (0.70). The allelic frequencies for IDH-s reported by Allendorf (1975) had to be revised, that author having hypothesized a single variable locus for the system (Appendix Table I). Finally, we tested the panmictic deviation at some loci; the $\chi^{2}$ values obtained are shown in Table IV. The gene diversity (Table V) and genetic distances (Table VI) were computed according to Neï (1975). The distance dendrogram is shown in Fig. 8. 
TABLE III

Allelic frequencies

\begin{tabular}{|c|c|c|c|c|c|c|}
\hline $\begin{array}{l}\text { System locus } \\
\text { and alleles }\end{array}$ & strain & $1-77 n=63$ & strain & $1-78 n=40$ & strain $2 n=60$ & strain ${ }^{3} n=40$ \\
\hline ADH Adh & & - & & fixed & - & fixed \\
\hline $\begin{array}{c}\text { CPK Cpk1 }(1.00) \\
\text { Cpk1 }(0.48) \\
\text { Cpk2 }\end{array}$ & & $\begin{array}{l}- \\
- \\
-\end{array}$ & & $\begin{array}{l}0.975 \\
0.025 \\
\text { fixed }\end{array}$ & $\begin{array}{l}- \\
-\end{array}$ & $\begin{array}{l}0.885 \\
0.115 \\
\text { fixed }\end{array}$ \\
\hline $\begin{aligned} \text { GOT } & \text { Got-1 } \\
& \text { Got-2(1.00) } \\
& \text { Got-2(1.17) }\end{aligned}$ & & $\begin{array}{l}- \\
- \\
-\end{array}$ & 0.562 & $\begin{array}{l}\text { fixed } \\
\left(X_{1}^{2}=0.74\right) \\
0.438\end{array}$ & - & $\begin{array}{c}\text { fixed } \\
0.650\left(X_{1}^{2}=0.58\right) \\
0.350\end{array}$ \\
\hline $\begin{aligned} \alpha \mathrm{GPDH} & \alpha \operatorname{gpdh} 1 \\
& \alpha \operatorname{gpdh} 2(\mathrm{a}) \\
& \alpha \operatorname{pdh} 2(\mathrm{~b})\end{aligned}$ & & $\begin{array}{l}\text { fixed } \\
0.984 \\
0.016\end{array}$ & & $\begin{array}{l}\text { fixed } \\
1.000 \\
0.000\end{array}$ & $\begin{array}{l}\text { fixed } \\
1.000 \\
0.000\end{array}$ & $\begin{array}{r}\text { fixed } \\
0.975 \\
0.025\end{array}$ \\
\hline $\begin{array}{l}\text { IDH-s Idh } 3 \text { and } 4 \\
\text { Idh }(1.00) \\
\text { Idh }(0.38) \\
\text { Idh }(0.62) \\
\text { (1) Idh }(1.31-1) \\
\text { (1) Idh }(1.31-2) \\
\text { Idh }(0.69)\end{array}$ & & $\begin{array}{l}0.595 \\
0.230 \\
0.024 \\
0.091 \\
0.012 \\
0.048\end{array}$ & & $\begin{array}{l}0.587 \\
0.250 \\
0.013 \\
0.081 \\
0.006 \\
0.063\end{array}$ & $\begin{array}{l}0.646 \\
0.154 \\
0.071 \\
0.046 \\
0.054 \\
0.029\end{array}$ & $\begin{array}{l}0.612 \\
0.244 \\
0.013 \\
0.031 \\
0.062 \\
0.038\end{array}$ \\
\hline $\begin{array}{ll}\text { IDH-m } & \text { Idh } 1 \\
& \text { Idh2(1.00) } \\
& \operatorname{Idh} 2(1.20)\end{array}$ & & $\begin{array}{l}- \\
- \\
-\end{array}$ & & $\begin{array}{l}\text { fixed } \\
0.850 \\
0.150\end{array}$ & $\begin{array}{l}- \\
- \\
-\end{array}$ & $\begin{array}{l}\text { fixed } \\
0.862 \\
0.138\end{array}$ \\
\hline LDH-M Ldh 1 and 2 & & - & & fixed & - & fixed \\
\hline LDH-H Ldh 3 and4 & & - & & fixed & - & fixed \\
\hline LDH-E Ldh 5 & & - & & fixed & - & fixed \\
\hline MDH-A Mdh 1 & & - & & fixed & - & fixed \\
\hline $\begin{array}{c}\text { MDH-B } \text { Mdh } 3 \text { and 4: } \\
\text { Mdh }(1.00) \\
\text { Mdh }(0.79) \\
\text { Mdh }(0.70) \\
\text { Mdh }(0.96)\end{array}$ & & $\begin{array}{l}0.716 \\
0.156 \\
0.083 \\
0.045\end{array}$ & & $\begin{array}{l}0.719 \\
0.156 \\
0.081 \\
0.044\end{array}$ & $\begin{array}{l}0.916 \\
0.071 \\
0.013 \\
0.000\end{array}$ & $\begin{array}{l}0.731 \\
0.160 \\
0.045 \\
0.064\end{array}$ \\
\hline PGI Pgi 1,2 and 3 & & - & & fixed & - & fixed \\
\hline $\begin{array}{r}\text { PGM Pgm }(1.00) \\
\text { Pgm }(0.70)\end{array}$ & 0700 & $\begin{array}{l}\left(X_{1}^{2}=0.57\right) \\
0.300\end{array}$ & 0.737 & $\begin{array}{l}\left(X_{1}^{2}=2.06\right) \\
0.263\end{array}$ & $\begin{array}{l}0.983 \\
0.017\end{array}$ & $\begin{array}{l}0.810 \\
0.190\end{array}$ \\
\hline $\begin{array}{l}\text { TO To }(1.00) \\
\text { To }(1.61) \\
\text { To }(0.39)\end{array}$ & 0340 & $\begin{array}{l}\left(X_{1}^{2}=0.12\right) \\
0.660 \\
0.000\end{array}$ & 0.275 & $\begin{array}{l}\left(X_{1}^{2}=1.01\right) \\
0.712 \\
0.013\end{array}$ & $\begin{array}{c}0.640\left(X_{1}^{2}=9.1^{*}\right) \\
0.280 \\
0.080\end{array}$ & $\begin{array}{c}0.350\left(X_{1}^{2}=0.01\right) \\
0.637 \\
0.013\end{array}$ \\
\hline $\begin{array}{r}\text { TFN Tfn (a) } \\
\text { Tfn (b) }\end{array}$ & & $\begin{array}{l}0.940 \\
0.060\end{array}$ & & $\begin{array}{l}0.962 \\
0.038\end{array}$ & $\begin{array}{l}0.992 \\
0.008\end{array}$ & $\begin{array}{l}0.975 \\
0.025\end{array}$ \\
\hline
\end{tabular}

Distinction between Idh (1.31-1) and Idh (1.31-2) is based on utilisation of two buffers : $0.1 \mathrm{M}$ Trisphosphate $\mathrm{pH} 7.4$ and $0.04 \mathrm{M}$ Sodium Citrate $\mathrm{pH} 5$.

$\mathrm{X}_{1}^{2}$ values correspond to tests of Hardy-Weinberg law $* 0.001<\mathrm{p}<0.005$

$\mathrm{n}=$ sample size

Intrapopulation Variability

\section{Discussion}

The four stocks studied $\left(S_{1}-77, S_{1}-78, S_{2}, S_{3}\right)$ showed a higher mean proportion of polymorphism than other populations. On account of the precautions taken, it would seem that the effect of the electrophoretic techniques can be eliminated, but no more precise reasons can be given for this variability of heterozygosity.

A highly polymorphic domesticated population may result from a mixture of natural populations which are less polymorphic but genetically differentiated or a high polymorphic natural population; this possibility cannot be rejected. Some steelhead populations are very polymorphic (computed from the data of Allendorf, 1975 


\section{TABLE IV}

Test of Hardy-Weinberg law for GOT under two hypothes

1) one locus is fixed 2) allele b is present at the two loci with the same frequency

\begin{tabular}{|c|c|c|c|c|c|c|}
\hline & \multicolumn{2}{|c|}{ Observed } & \multicolumn{2}{|c|}{$\begin{array}{c}\text { Expected } \\
\text { (hypothesis 1) }\end{array}$} & \multicolumn{2}{|c|}{$\begin{array}{c}\text { Expected } \\
\text { (hypothesis 2) }\end{array}$} \\
\hline & $\begin{array}{c}\text { Strain } \\
1-78\end{array}$ & $\begin{array}{c}\text { Strain } \\
3\end{array}$ & $\begin{array}{l}\text { Strain } \\
1-78\end{array}$ & $\begin{array}{c}\text { Strain } \\
3\end{array}$ & $\begin{array}{c}\text { Strain } \\
1-78\end{array}$ & $\begin{array}{c}\text { Strain } \\
3\end{array}$ \\
\hline aaaa & 14 & 18 & 12.5 & 16.9 & 3.93 & 7.14 \\
\hline aaab & 17 & 16 & 19.7 & 18.2 & 12.36 & 15.38 \\
\hline$a a b b$ & 9 & 6 & 7.8 & 4.9 & 14.57 & 12.42 \\
\hline$a b b b$ & 0 & 0 & 0 & 0 & 7.63 & 4.46 \\
\hline bbbb & 0 & 0 & 0 & 0 & 1.50 & 0.6 \\
\hline \multicolumn{3}{|c|}{$\mathrm{X}^{2}=$} & $\mathrm{X}_{1}^{2}=0.74$ & $X_{1}^{2}=0.52$ & \multicolumn{2}{|c|}{$\mathrm{X}_{2}^{2}=38.8^{*} \mathrm{X}_{2}^{2}=24.92^{*}$} \\
\hline
\end{tabular}

$*:<0.0005$

for the same subsample of eight loci, $H=0.31$ in a natural steelhead population, and the resident forms which do not seem to be genetically differentiated from the migratory ones might exhibit the same degree of polymorphism.

Although it is impossible to choose between these two possibilities, we can conclude that introduction and breeding have not led to a reduction of the intrapopulation genetic variability of these stocks. Such processes, however, seem to operate . in some populations, as in the stock of the University of Washington (Allendorf, 1975).

Table $V$ shows the proportion of heterozygosity of stocks $S_{1}-78$ and $S_{3}$ computed from the whole of the systems studied. The values in parentheses correspond to monomorphic $\mathrm{Mdh}_{4}$ and $\mathrm{Idh}_{4}$ loci, all the variations of the MDH-A and IDH-s systems being reported to the $\mathrm{Mdh}_{3}$ and $\mathrm{Idh}_{3}$ loci, respectively.

Allendorf and Utter (1978) have demonstrated that rainbow trout are highly polymorphic as compared to other salmonids. Comparisons with other species entail some corrections; the mean value of intrapopulation variability $(0.22)$ was computed for eight loci, seven of which were very polymorphic in the rainbow trout. Using

TABLE V

Heterozygosity levels

\begin{tabular}{llc}
\hline \hline & 8 loci & 25 loci \\
\hline $\mathrm{S}_{1}-77$ & 0.348 & \\
$\mathrm{~S}_{1}-78$ & 0.336 & $0.149(0.125)$ \\
$\mathrm{S}_{2}$ & 0.241 & \\
$\mathrm{~S}_{3}$ & 0.324 & $0.149(0.134)$ \\
Univ. of Washington* & 0.086 & \\
Chamber Creek** & 0.228 & \\
Mac Creary* & 0.210 & \\
West Virginia* & 0.088 & \\
RTH** & 0.171 & \\
RTHX** & 0.174 & \\
RTS** & 0.214 & \\
RTW** & 0.295 & \\
RTV** & 0.150 & \\
\hline
\end{tabular}

*Allendorf (1975).

**Busack et al. (1979). 


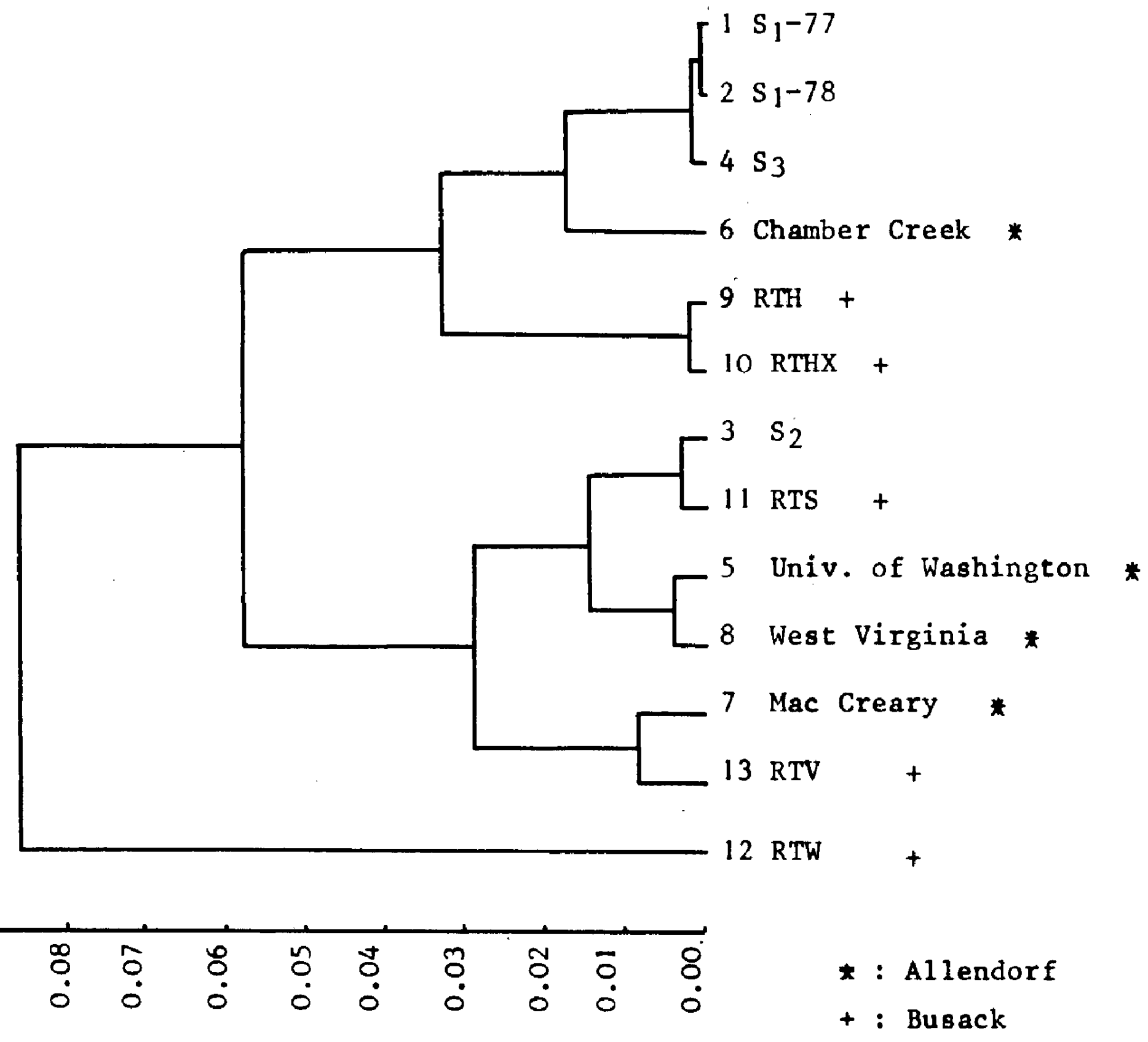

FIG. 8. Dendrogram of genetic distances between 13 populations of domesticated rainbow trout.

some of Allendorf's data (1975) taken from a more representative sample of the whole of the loci generally used for estimating the proportion of heterozygosity, we obtained a correct estimate of $\mathrm{H}_{\mathrm{c}}=0.063$. Other vertebrates (28 species in Fuerst et al., 1977) shown a mean value of $0.038(\mathrm{SD}=0.033)$ after elimination of very variable esterases $\left(\mathrm{H}_{\text {esterases }}=0.134\right.$ for the 28 species $)$ which Allendorf did not study.

\section{Interpopulation Variability}

Samples $S_{1}-78$ and $S_{1}-77$, representing two successive groups from the same fish farms, were almost identical. This frequency stability, which should be followed through several generations, has been reported several times (Altukhov et al., 1975; Busack et al., 1979), and shows the repeatability of the method, the representative nature of the samples and the advantage of this technique as a tool for the genetic description of species and populations.

Table VII gives the analysis of overall genetic variance into mean intrapopulation genic diversity and mean interpopulation genetic distance for the whole of the 
TABLE VI

Genetic distances matrix

\begin{tabular}{|c|c|c|c|c|c|c|c|c|c|c|c|c|}
\hline & $S_{1}-77$ & $S_{1}-78$ & $\mathrm{~S}_{2}$ & $S_{3}$ & $\begin{array}{l}\text { Univ. of } \\
\text { Wash- } \\
\text { ington }\end{array}$ & $\begin{array}{l}\text { Chamber } \\
\text { Creek }\end{array}$ & $\begin{array}{c}\text { Mac } \\
\text { Creary }\end{array}$ & $\begin{array}{c}\text { West } \\
\text { Virginia }\end{array}$ & RTH & RTHX & RTS & RTW \\
\hline$S_{1}-78$ & 0.00074 & & & & & & & & & & & \\
\hline S2 & 0.03222 & 0.03537 & & & & & & & & & & \\
\hline S3 & 0.00199 & 0.00187 & 0.02244 & & & & & & & & & \\
\hline Univ. of Washington & 0.08566 & 0.09356 & 0.02039 & 0.07180 & & & & & & & & \\
\hline Chambẹr Creek & 0.01723 & 0.01984 & 0.02809 & 0.01586 & 0.05575 & & & & & & & \\
\hline Mac Creary & 0.03041 & 0.03422 & 0.01958 & 0.02421 & 0.04200 & 0.01395 & & & & & & \\
\hline West Virginia & 0.07047 & 0.07624 & 0.01492 & 0.05664 & 0.00402 & 0.03935 & 0.02380 & & & & & \\
\hline RTH & 0.03392 & 0.02976 & 0.07363 & 0.03393 & 0.14328 & 0.03085 & 0.04641 & 0.10914 & & & & \\
\hline RTHX & 0.03601 & 0.03345 & 0.08196 & 0.03914 & 0.14881 & 0.02855 & 0.04777 & 0.11464 & 0.00216 & & & \\
\hline RTS' & 0.03364 & 0.03793 & 0.00318 & 0.02518 & 0.01507 & 0.02115 & 0.01382 & 0.00857 & 0.07179 & 0.07709 & & \\
\hline RTW & 0.06608 & 0.07270 & 0.03431 & 0.05959 & 0.06079 & 0.09349 & 0.08266 & 0.07069 & 0.06102 & 0.17174 & 0.04840 & \\
\hline RTV & 0.05003 & 0.05183 & $0.03038^{\circ}$ & 0.03834 & 0.04991 & 0.02744 & 0.00831 & 0.02875 & 0.05297 & 0.05878 & 0.02446 & 0.11060 \\
\hline
\end{tabular}


TABLE VII

Analysis of genic diversity $H=\frac{\sum_{j} H_{j}}{N}+\frac{1}{N^{2}} \sum \sum_{j^{\prime}} D$

\begin{tabular}{lcc}
\hline \hline Population grouping & $\begin{array}{c}\text { Genic diversity } \\
\text { intrapopulation } \frac{\Sigma \mathrm{Hj}}{\mathrm{N}}\end{array}$ & $\begin{array}{c}\text { Average genetic } \\
\text { distance } \frac{\Sigma \Sigma \mathrm{Dj}^{\prime}}{\mathrm{N}^{2}}\end{array}$ \\
\hline $\mathrm{H}_{\mathrm{T}}:$ (all 13 populations) & 0.210 & 0.048 \\
\hline $\mathrm{H}_{1}:$ (the 4 French populations) & 0.302 & 0.013 \\
\hline $\mathrm{H}_{2}:$ (the other 9 populations) & 0.179 & 0.052 \\
\hline $\mathrm{H}_{\mathrm{T}}^{\prime}: \begin{array}{l}\text { (French populations and } \\
\text { consican populations }\end{array}$ & 0.270 & 0.006 \\
\hline$\ldots$
\end{tabular}

13 populations $\left(\mathrm{H}_{\mathrm{T}}\right)$, the four stocks studied $\left(\mathrm{H}_{1}\right)$, the other nine populations $\left(\mathrm{H}_{2}\right)$, as well as the classification obtained when the French populations and the American populations were considered as two different units $\left(\mathrm{H}_{\mathrm{T}}^{\prime}\right)$.

The mean genetic distance within the groups $S_{1}, S_{2}$ and $S_{3}$ is lower $(0.013$ vs. 0.052 ), indicating strong homogeneity. However, examination of $H_{T}^{\prime}$ does not reveal any significant differentiation between the two groups. This is illustrated by the genetic distribution dendrogram in Fig. 8.

The constitution of French stocks began about 100 years ago with populations introduced from North America. These introductions, which are still in progress either directly or by the intermediary of some European country or other continents, are difficult to trace. However, it would appear from this preliminary study that a large part of the genetic variability of the rainbow trout species is present in the stocks studied and that the isolation of these groups for several generations has not caused significant genetic differentiation, as compared to all the domesticated strains studied.

\section{References}

Allendorf, F. W. 1975. Genetic variability in a species possessing extensive gene duplication; Genetic interpretation of duplicate loci and examination of genetic variation in populations of rainbow trout. Ph.D. Thesis, Univ. Washington, Seattle. pp. 98.

Allendorf, F. W and Utter, F. M. -1973. Gene duplication within the family salmonidae; Disomic inheritance of two loci reported to be tetrasomic in rainbow trout. Genetics, 74: 647-654.

Allendorf, F. W. and Utter, F. M. 1974. Biochemical genetic systematics of the genus salmon. Anim. Blood Groups Biochem. Genet. 5(Suppl. 1): 33. Abstr.

Allendorf, F. W. and Utter, F. M. 1978. Population genetics of fish. In Fish physiology. Edited by W. S. Hoar, D. J. Randall and J. R. Breet. Academic Press, New York. 8: 407-545.

Altukhov, Y. P., Salmenkova, F. A., Konovalov, S. M. and Padoukin, A. I. 1975. Stationary distributions of frequencies of lactate dehydrogenase and phosphoglucomutase genes in population system of local fish stock Oncorhynchus nerka.' 1. Stability of the stock in generations under simultaneous variability of subpopulations making up their structure. Genetika, 11: 44-53.

Avise, J. C. and Kitto, G. B. 1973. Phosphoglucose isomerase gene duplication in the bony fishes: An evolutionary history. Biochem. Genet. 8: 113-13i.

Bailey, G. S., Wilson, A. G., Halver, J. E. and Johnson, C. L. 1970.' Multiple forms of supernatant malate dehydrogenase in salmonid fishes: Biochemical, immunological and genetic studies. J.Biol.Chem. 245: $5927-5940$.

Bailey, G. S., Tsuyuki, H. and Wilson, A. C. 1976. The number of genes for lactate dehydrogenase in salmonid fishes. J. Fish. Res. Board Can. 33: 760-767.

Behnke, R. J. 1972. The systematics of salmonid fishes or recently glaciated lakes. I. Subfamily salmonidae. J. Fish. Res. Board Can. 29: 639-671. 
Busack, C. A., Halliburton, R. and Gall, G. A. E. 1979. Electrophoretic variation and differentiation in four strains of domesticated rainbow trout (Salmo gairdneri). Can. J. Genet. Cytol. 21: 81-94.

Clayton, J. W. and Tretiak, D. N. 1972. Amino-citrate buffers for $\mathrm{pH}$ control in starch gel electrophoresis. J. Fish. Res. Board Can. 29: 1169-1172.

Cross, T. F. and Payne, R. H. 1977. Nadp-isocitrate dehydrogenase polymorphism in the Atlantic salmon Salmo salar. J. Fish. Biol. 11: 493-496.

Fuerst, P. A., Chakraborty, R and Nei, M. 1977. Statistical studies on protein polymorphism in natural population. I. Distribution of single locus heterozygosity. Genetics, 86: 455-483.

Gold, J. R. 1977. Systematics of western North American trout (Salmo) with notes on the redband trout of Sheepheaven Creek, California. Can. J. Zool. 55: 1858-1873.

Mac Crimmon, R. H. 1971. World distribution of rainbow trout (Salmo gairdneri) J. Fish. Res. Board Can. 28: 663-704.

May, B., Wright, J. E. and Stoneking, M. 1979. Joint segregation of biochemical loci in salmonidae; Results from experiments with Salvelinus and review of the literature on other species. J. Fish. Res. Board Can. 36: 1114-1128.

Nei, M. 1975. Molecular population genetics and evolution. North-Holland, Amsterdam and New York.

Ridgway, G. J., Sherburne, S. W. and Lewis, R. D. 1970. Polymorphisms in the esterases of Atlantic herring. Trans. Am. Fish. Ser. C, 99: 147-151.

Roberts, F. L., Wohnus, J. F. and Ohno, S. 1969. Phosphoglucomutase polymorphism in the rainbow trout, Salmo gairdneri. Experientia, 25: 1109-1110.

Schmidtke, J., Dunkhase, G. and Engel, W. 1975. Genetic variation of phosphoglucose isomerase isoenzymes in fish of the orders ostariophysi and isospondyli. Comp. Biochem. Physiol. 50B: 395398.

Utter, F. M. and Allendorf, F. W. 1977. Determination of the breeding structure of steelhead populations through gene frequency analysis. Edited by T. J. Hassler and R. R. Van Kirk. Calif. Coop. Fisheries Res. Unit, Spec. Report. pp. 1-77.

Utter, F. M., Hodgins, H. O., Allendorf, F. W., Johnson, A. G. and Mighell, J. L. 1973. Biochemical variants in Pacific salmon and rainbow trout; their inheritance and application in population studies. In Genetics and mutagenesis of fish. Edited by H. H. Schroder. Springer-Verlag, Berlin, Heidelberg, New York.

Wright, J. E., Heckman, J, R. and Atherton, L. M. 1975. Genetic and developmental analysis of LDH Isozymes in trout. In lsozymes, III, Developmental biology. Edited by C. L. Markert. Academic Press, New York. 
APPENDiX TABLE I

Allelic frequencies for comparison of the 13 strains of domesticated rainbow trout

\begin{tabular}{|c|c|c|c|c|c|c|c|c|c|c|c|c|c|}
\hline & $S_{1}-77$ & $S_{1}-78$ & $S_{2}$ & $S_{3}$ & $\begin{array}{l}\text { Univ. of } \\
\text { Wash- } \\
\text { ington }\end{array}$ & $\begin{array}{c}\text { Chamber } \\
\text { Creek }\end{array}$ & $\begin{array}{c}\text { Mac } \\
\text { Creary }\end{array}$ & $\begin{array}{c}\text { West } \\
\text { Virginia }\end{array}$ & RTH & RTHX & RTS & RTW & RTV \\
\hline & \multicolumn{13}{|c|}{ Locus Agpdh-2 } \\
\hline$\alpha$-gpdh (b) & 0.0160 & 0.0 & 0.0 & 0.0250 & 0.0 & 0.0 & 0.1120 & 0.0 & 0.0020 & 0.0030 & 0.0 & 0.0090 & 0.2510 \\
\hline \multirow[t]{2}{*}{$\alpha$-gpdh (a) } & 0.9840 & 1.000 & 1.0000 & 0.9750 & 1.0000 & 1.00000 & 0.8880 & 1.0000 & 0.9980 & 0.9970 & 1.0000 & 0.9910 & 0.7490 \\
\hline & \multicolumn{13}{|c|}{ Locus Idh-3 } \\
\hline Idh-3 (1.31) & 0.1030 & 0.0870 & 0.1000 & 0.0930 & 0.0065 & 0.0 & 0.1000 & 0.0 & 0.0010 & 0.0 & 0.0240 & 0.3820 & 0.0 \\
\hline Idh $-3(1.00)$ & 0.5950 & 0.5870 & 0.6460 & 0.6120 & 0.8125 & $0.7790^{\circ}$ & 0.8735 & 0.8750 & 0.6990 & 0.7330 & 0.7440 & 0.3400 & 0.9260 \\
\hline Idh-3 (0.69) & 0.0720 & 0.0760 & 0.1000 & 0.0510 & 0.0 & 0.0 & 0.0 & 0.0 & 0.1730 & 0.1580 & 0.1030 & 0.0750 & 0.0 \\
\hline \multirow[t]{2}{*}{ Idh-3 (0.38) } & 0.2300 & 0.2500 & 0.1540 & 0.2440 & 0.1810 & 0.2210 & 0.0165 & 0.1250 & 0.1270 & 0.1080 & 0.1280 & 0.2030 & 0.0740 \\
\hline & \multicolumn{13}{|c|}{ Locus Idh-4 } \\
\hline Idh-4 (1.31) & 0.1030 & 0.0870 & 0.1000 & 0.0930 & 0.0065 & 0.0 & 0.0 & 0.0 & 0.0010 & 0.0 & 0.0240 & 0.3820 & 0.0 \\
\hline Idh-4 (1.00) & 0.5950 & 0.5870 & 0.6460 & 0.6120 & 0.8125 & 0.7790 & 0.8735 & 0.0 & 0.6990 & 0.7330 & 0.7440 & 0.3400 & 0.9260 \\
\hline Idh-4 (0.69) & 0.0720 & 0.0760 & 0.1000 & 0.0510 & 0.0 & 0.0 & 0.0 & 0.8750 & 0.1730 & 0.1580 & 0.1030 & 0.0750 & 0.0 \\
\hline \multirow[t]{2}{*}{ Odh $=4(0.38)$} & 0.2300 & 0.2500 & 0.1540 & 0.2440 & 0.1810 & 0.2210 & 0.0165 & $\begin{array}{l}0.0 \\
0.1250\end{array}$ & 0.1270 & 0.1080 & 0.1280 & 0.2030 & 0.0740 \\
\hline & \multicolumn{13}{|c|}{ Locus Mdh-3 } \\
\hline Mdh-3 (1.25) & 0.0 & 0.0 & 0.0 & 0.0 & 0.0 & 0.0 & 0.0060 & 0.0 & 0.0 & 0.0 & 0.0 & 0.0060 & 0.0 \\
\hline Mdh-3 (1.00) & 0.7610 & 0.7630 & 0.9160 & 0.7950 & 0.9810 & 0.9530 & 0.9380 & 1.0000 & 0.9990 & 1.0000 & 0.9150 & 0.7520 & 1.0000 \\
\hline \multirow[t]{2}{*}{$\overline{M d h}-3(0.79)$} & 0.2390 & 0.2370 & 0.0840 & 0.2050 & 0.0190 & 0.0470 & 0.0570 & 0.0 & 0.0010 & 0.0 & 0.0850 & 0.2420 & 0.0 \\
\hline & \multicolumn{13}{|c|}{ Locus Mdh-4 } \\
\hline Mdh-4 (1.25) & 0.0 & 0.0 & 0.0 & 0.0 & 0.0 & 0.0 & 0.0060 & 0.0 & 0.0 & 0.0 & 0.0 & 0.0060 & 0.0 \\
\hline Mdh-4 (1.00) & 0.7610 & 0.7630 & 0.9160 & 0.7950 & 0.9810 & 0.9530 & 0.9380 & 1.0000 & 0.9990 & 1.0000 & 0.9150 & 0.7520 & 1.0000 \\
\hline \multirow[t]{2}{*}{$M d h-4(0.79)$} & 0.2390 & 0.2370 & 0.0840 & 0.2050 & 0.0190 & 0.0470 & 0.0570 & 0.0 & 0.0010 & 0.0 & 0.0850 & 0.2420 & 0.0 \\
\hline & \multicolumn{13}{|c|}{ Locus Pgm } \\
\hline $\operatorname{Pgm}(1.00)$ & 0.7000 & 0.7370 & 0.9830 & 0.8100 & 1.0000 & 0.6390 & 0.8250 & 1.0000 & 0.6840 & 0.5610 & 0.9200 & 1.0000 & 0.9690 \\
\hline \multirow[t]{2}{*}{ Pgm $(0.70)$} & 0.3000 & 0.2630 & 0.0170 & 0.1900 & 0.0 & 0.3610 & 0.1750 & 0.0 & 0.3160 & 0.4390 & 0.0800 & 0.0 & 0.0310 \\
\hline & \multicolumn{13}{|c|}{ Locus Sod } \\
\hline Sod $(1.61)$ & 0.6600 & 0.7120 & 0.2800 & 0.6370 & 0.0 & 0.5580 & 0.5000 & 0.1560 & 1.000 & 0.9800 & 0.2950 & 0.1170 & 0.5570 \\
\hline Sod $(1.00)$ & 0.3400 & 0.2725 & 0.6400 & 0.3500 & 1.000 & 0.4420 & 0.5000 & 0.8440 & 0.0 & 0.0200 & 0.7050 & 0.8830 & 0.4420 \\
\hline Sod $(0.39)$ & 0.0 & 0.0130 & 0.0800 & 0.0130 & 0.0 & 0.0 & 0.0 & 0.0 & 0.0 & 0.0 & 0.0 & 0.0 & 0.0 \\
\hline
\end{tabular}

